\title{
THE PSYCHOLOGY OF INFANT LANGUAGE.
}

\section{BY PROFESSOR JOHN DEWEY,}

Utiversity of Michigan.

In his interesting and valuable article on The Language of Childhood, * Mr. Tracy undertakes, upon a basis of 5400 words used by at least twenty different children, to determine the relative frequency of the various parts of speech. Before making some remarks, I wish first to submit my own mite for the further use of students. A refers to a boy; B to a girl, 20 months younger. $\dagger$

\begin{tabular}{|c|c|c|c|c|c|}
\hline \multicolumn{3}{|c|}{$A$ at ig mos. old. } & \multicolumn{3}{|c|}{$B \ddagger$ at I8 mos. old. } \\
\hline Parts of Speec & & Per cent. & Parts of Speecl & & Per cent. \\
\hline Nouns. . & 68 & & Nouns. . & 76 & 53 \\
\hline Verbs. & 24 & $2 \mathrm{I}$ & Verbs . & 40 & 28 \\
\hline Adjectives . & 13 & I I & Adjectives & 2 & I \\
\hline Adverbs. & 4 & 3 & Adverbs. & 9 & 6 \\
\hline Interjections & 6 & 5 & Interjections & 7 & 5 \\
\hline Total . & II 5 & 100 & Conjunctions & $\begin{array}{l}0 \\
2\end{array}$ & I \\
\hline $\begin{array}{l}\text { Pronouns, } \\
\text { junctions, }\end{array}$ & $\begin{array}{l}\text { repos } \\
\text { none. }\end{array}$ & , con- & $\begin{array}{l}\text { Total } \\
\text { Prepositions }\end{array}$ & 4 & 100 \\
\hline
\end{tabular}

For purposes of comparison, I append the per cents reached by Mr. Tracy by averaging all his results:

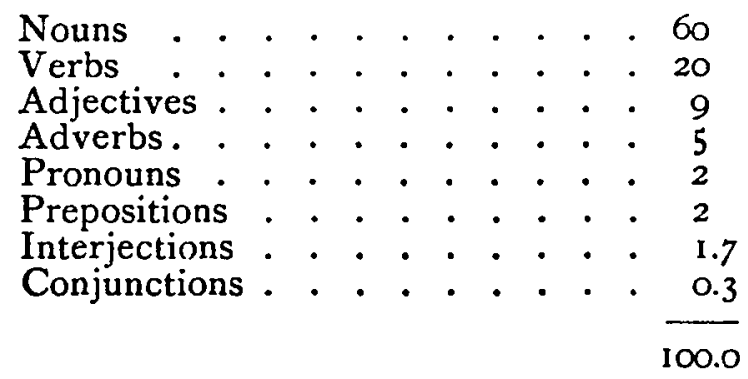

* Am. Jour. Psychol., vol. vi., No. I, reprinted in The Psychology of Childhood, Boston, Heath \& Co., 1893.

$\uparrow$ The presence of other children in the family should always, I think, form part of the data with reference to a child's vocabulary. At least, it is one of the old wives' saws on this matter that the presence of other children both hastens and extends a vocabulary.

¥A's vocabulary was kept continuously; B's vocabulary was taken from words actually used within a period of five or six days; a number of words contained in her vocabulary four months previously do not appear at all. 
I wish to remark (I) concerning the relative frequency of verbs, and (2) concerning the different rates of distribution in different children :

I. Mr. Tracy notes that since the relative frequency of verbs in the language is but i I per cent, the child, comparatively speaking, uses verbs with $\mathrm{I} .8 \mathrm{I}$ the ease with which he uses nouns, and makes some judicious remarks concerning the prevalence of concepts of activity in the child mind. I think he could make his case much stronger. Mr. Tracy, I take it, has classified his words according to the sense which they have to an adult, and I have followed that principle in my own table.* In a sense, however, this is as artificial as Mr. Tracy notes that it is to put knife under $k$ instead of under $n$, because we spell it with a $k$. The psychological classification is to class the word according to what it means to a child, not to an adult with his grammatical forms all differentiated.

Such a classification would in all probability increase immensely the percentage of verbs. It is true that such a method demands much more care in observation, and opens the way to the very variable error of interpretation; but the greater certainty of the method followed above is after all only seeming-it does not express the child's vocabulary, but our interpretation of it according to a fixed but highly conventional standard. It is out of the question to redistribute the language of $A$ and $B$, given above; but $I$ subjoin the vocabulary of a child in his tweith month where contemporaneous observation makes me reasonably sure of what the child means:

See there; bye-bye; bottle; papa; mamma; grandma; Freddy; burn; fall; water; down; door; no, no; stop; thank you; boo (peek-a-boo); daw (used when he sees anything which he wants given to him)-r 7 in all.

Of the above, only the four proper nouns are, psychologically speaking, names of objects. Water is a verb as well as

* Phrases like 'all light,' ' all dark,' 'all gone,' ' out' (for 'go out'), etc., I have treated as verbs. It is obvious that they might be considered either as interjections or as adjectives. The relatively larger per cent of verbs in my table may be due to this classification. 
a noun; door is always accompanied by gestures of reaching, and an attempt to swing the door back and fro; 'daw' is apparently a request, an expression of expectation of something good to eat and the name of a thing all together; bottle certainly has adjectival and verbal implications as well as nominal. At present I should regard it as a complex, ' nominal-adjectivalverbal,' the emphasis being on the noun, while six weeks previously it was, say, 'verbal-adjectival-nominal.' 'Stop'; ' no, no'; 'burn'; 'see there', etc., are equally interjections and verbs. 'Thank you' is at times a request for something, and is almost invariably said when giving an article to any one else. We have then a graded and continuous series, so far as sense is concerned, the proper names ( 23 per cent) at one end, and the interjectional forms 'no, no', 'peek-a-boo', at the other. These have a verbal coloring, however. Between these classes are a nominal-adjectival-verbal-interjectional complex, the verbalinterjectional meaning prevailing on the whole, the adjectiva! in all cases subordinate. ${ }^{*}$ The tendency to apply the same term to a large number of objects ('ball' to ball, orange, moon, lamp-globe, etc.) can be understood, I think, only if we keep in mind the extent to which the formal noun, 'ball,' has really an active sense. 'Ball' is 'to throw' just as much as it is the round thing. I do not believe that the child either confuses the moon with his ball, or abstracts the roundness of it; the roundness suggests to him something which he has thrown, so that the moon is something to throw-if he could only get hold of it.

What I would suggest, then, along the line of a study of the distribution of vocabulary into parts of speech is such observation and record as would note carefully the original sense to the child of his words, and the gradual differentiation

* The fact that interjections fail so late, as a rule, in aphasia, taken with the highly immediate and emotional character of child-life, indicates the defective character of a method of classification which reduces the percentage of interjections to 1.7. The philologist's objections to making interjections a primitive form of speech, bowever sound grammatically, seem to me to rest upon attaching a limited, technical sense to the concept interjection, which is without ground psychologically. In the infant mind (whether race or child) the emotional state and the tendency to react aroused by an object must, I should say, be fused, and both precede any clear recognition of the 'object' as such, or of any objective quality. 
of the original protoplasmic verbal-nominal-interjectional form (as it seems to me), until words assume their present rigidity.

2. No one can examine the statistics given without being struck by the great differences in different children. $F$, in Mr. Tracy's tables, has 15 per cent interjections; while $K$, with a vocabulary of 250 words, has none at all. $F$ has II per cent adverbs; while $\mathrm{K}$ has but 2 per cent; in my own table, A has 4, while B has 9 per cent. So in my two, A has I I per cent adjectives; $B$, I per cent; while Mr. Tracy's vary from a maximum of 13 to a minimum of 3 per cent. I believe the tendency in all psychological investigation, at present, is to attempt to get a uniform mathematical statement, eliminating individual differences; for pedagogical and ethical purposes, at least, it is these differences which are, finally, most important. And on strictly psychological grounds the varying ratio of adverbs and pronouns on one side and nouns and adjectives on the other must denote a very different psychological attitude-different methods of attaching interest and distributing attention. Observation of different mental traits as connected with these linguistic differences would not only add to the terra incognita, individual psychology (and it would seem that all psychology must be finally individual), but throw great light upon the psychology of language. How vague and formal at present our answers, for example, when we are asked to what psychological state and need an adverb corresponds!

\section{WORK AT THE YALE LABORATORY.}

\section{BY E. W. SCRIPTURE.}

The first year in the life of a laboratory is one of incredible difficulties and incessant labor in getting matters arranged. Nevertheless, we have been able to carry on several investigations and bring them to succe'ssful conclusion and publication.*

The most extensive investigation was that by C. B. Bliss on reaction-time and attention. The graphic method was developed so that records absolutely accurate to thousandths of

* Studies from the Yale Psychological Laboratory, 1892-1893, edited by E. W. Scripture, New Haven, 1893. 